\title{
Analisa Dampak Saluran Lindi Terhadap Lingkungan Dilihat Dari Aspek Pengelolaan TPA
}

\author{
Ayu Nur Fitriani Busanto ${ }^{1}$, Erina Rahmadyanti ${ }^{2}$ \\ ${ }^{12}$ Program Studi Teknik Sipil, Fakultas Teknik, Universitas Negeri Surabaya \\ Email: 1ayu.17050724013@mhs.unesa.ac.id, ${ }^{2}$ erinarahmadyanti@unesa.ac.id
}

\begin{abstract}
The existence of waste is still a problem that affects almost all regions in Indonesia. Leachate is a liquid produced from the decomposition of waste in landfills which can seep into the ground and can contaminate groundwater and its surroundings. Until now, waste management, such as recycling waste or directly dumping it into a landfill, can be done using the Landfill method (landfilling) or an incinerator (incineration) is still needed to solve the waste problem. This discussion is to examine the impact of leachate channels on the environment, leachate management systems and land requirements. This study was conducted at the location of the Kenep Final Disposal Site in Pasuruan Regency. Therefore, efforts to manage existing leachate water are needed before discharge to a receiving water body or river. In this discussion, the leachate discharge value of 0,689 lt/dt was obtained so that the results for the dimensions of the Leachate Management Installation were obtained for the Stabilization Pool area $85.04 \mathrm{~m}^{2}$, depth of $3.5 \mathrm{~m}$, long $10 \mathrm{~m}$, wide $8.5 \mathrm{~m}$, and an efficiency of 67\%. The Facultative pool area $198.43 \mathrm{~m}^{2}$, depth of $3 \mathrm{~m}$, long $15 \mathrm{~m}$, wide $13.23 \mathrm{~m}$, and an efficiency of 50\%. The Maturation Pool area $198.43 \mathrm{~m}^{2}$, depth of $3 \mathrm{~m}$, long $15 \mathrm{~m}$, wide $13.23 \mathrm{~m}$ and an efficiency of 50\%. And it takes a widening of the area for the Kenep Final Disposal Site in Pasuruan Regency by 0.6 hectares or $6000 \mathrm{~m}^{2}$.
\end{abstract}

Keywords: Garbage, Leachate Drain, Leachate Water, Pasuruan, TPA.

Keberadaan sampah sampai saat ini masih menjadi permasalahan yang melanda hampir di seluruh wilayah di Indonesia. Air lindi merupakan sebuah cairan yang dihasilkan dari dekomposisi sampah di tempat pembuangan akhir yang dapat merembes ke dalam tanah dan dapat mencemari air tanah dan sekitarnya. Hingga saat ini pengelolaan sampah seperti daur ulang sampah ataupun langsung di buang ke tempat pembuangan akhir sampah dapat dilakukan dengan metode Landfill (menimbun sampah dengan tanah) atau insinerator (pembakaran) ini masih dibutuhan dalam mengatasi permasalahan sampah. Pembahasan ini untuk mengkaji dampak saluran air lindi terhadap lingkungan, sistem pengelolaan air lindi dan kebutuhan lahan. Kajian ini dilakukan dilokasi Tempat Pembuangan Akhir Kenep Kabupaten Pasuruan maka perlu upaya pengelolaan terhadap air lindi yang ada sebelum dilakukan pembuangan ke badan air penerima atau sungai. Pada pembahasan ini didapatkan nilai debit air lindi yang sebesar $0.689 \mathrm{lt} / \mathrm{dt}$ sehingga hasil untuk dimensi Instalasi Pengelolaan Lindi didapatkan untuk Kolam Stabilisasi yaitu luas sebesar $85.04 \mathrm{~m}^{2}$, kedalaman sebesar $3.5 \mathrm{~m}$, panjang $10 \mathrm{~m}$, lebar $8.5 \mathrm{~m}$, dan hasil efisiensi sebesar $67 \%$. Kolam Fakultatif yaitu luas sebesar $198.43 \mathrm{~m}^{2}$, kedalaman sebesar $3 \mathrm{~m}$, panjang $15 \mathrm{~m}$, lebar $13.23 \mathrm{~m}$ dan hasil efisiensi sebesar 50\%. Kolam Maturasi yaitu luas sebesar $198.43 \mathrm{~m}^{2}$, kedalaman sebesar $3 \mathrm{~m}$, panjang $15 \mathrm{~m}$, lebar $13.23 \mathrm{~m}$ dan hasil efisiensi sebesar 50\%. Dan dibutuhkan pelebaran luas area untuk Tempat Pembuangan Akhir Kenep di Kabupaten Pasuruan sebesar 0.6 hektar atau 6000 m².

Kata Kunci : Air Lindi, Pasuruan, Sampah, Saluran Lindi, TPA.

\section{Pendahuluan}

Keberadaan sampah sampai saat ini tengah menjadi permasalahan yang melanda hampir di seluruh wilayah di Indonesia. Berbagai program dan strategi dilakukan pemerintah baik daerah maupun pusat untuk mengatasi berbagai permasalaan yang ditimbulkan oleh sampah khususnya dalam hal pengelolaan sampah. Pengelolahan sampah adalah tanggung jawab pemerintah sebagai salah satu bentuk pelayanan publik dengan membuat kebijakan dalam pengelolaan sampah [1]. Sampah yaitu material yang mempunya nilai buruk secara ekonomi maupun lingkungan sehingga akhirnya dibuang. Kuantitas sampah yang terdapat di lingkungan perkotaan setiap tahun terus meningkat seiring 
bersamanya bertambahnya jumlah penduduk serta pola hidup masyarakat itu sendiri yang cenderung lebih konsumtif dan banyak menggunakan bermacam-macam barang yang digunakan.

Pertumbuhan jumlah penduduk dengan perubahan pola konsumsi masyarakat menimbulkan bertambahnya jenis, volume dan karakteristik sampah semakin beragam sehingga dapat mempengaruhi lingkungan [2]. Tempat Pembuangan Akhir (TPA) ialah tempat yang digunakan untuk menampung sampah yang sudah mencapai tahap akhir dalam pengumpulan sampah yang dimulai dari pertamakali sampah tersebut dihasilkan, dikumpulkan, diangkut, dikelola dan dibuang. TPA merupakan tempat dimana sampah sudah mencapai tahap akhir dan merupakan lokasi yang harus jauh dan terpisah secara baik hingga tidak dapat menimbulkan akibat buruk bagi lingkungan sekitar TPA [3].

Air Lindi atau (Leachate) merupakan cairan yang keluar dari rembesan tumpukan sampah dengan membawa zat telarut atau tersuspensi dari hasil proses dekomposisi sampah. Air Lindi bisa masuk kedalam tanah dan membuat pencemaran tanah serta air tanah secara langsung karena didalam kandungan air lindi terdapat berbagia macam senyawa kimia anorganik dan organik serta sejumlah pathogen untuk memperbaiki permasalahan lindi yang terjadi perlu upaya pengelolaan lindi di lokasi TPA [4]. Kualitas airlindi bergantung dari hal yang mempengaruhinya seperti temperatur, musim, curah hujan, Infiltrasi air tanah, kelembapan, variasi proporsi komponen sampah yang ditimbun, umur timbunan, tahap dekomposisi, dan waktu dilakukan pengambilan uji sampling. Pada tahap awal banyak ditemukan kandungan senyawa organik dengan berat molekul yang kecil berasal dari senyawa yang lambat terdekomposisi [5]. Secara garis besar, COD (Chemical Oxygen Demang), BOD (Biological Oxygen Demand) dari NH3-N berasal dari kandungan lindi akan mengalami perubahan seiring berjalannya waktu. BOD akan berkurang lebih cepat dibandingkan dengan COD karena BOD tersusun dari zat organik yang sangat mudah terdekomposisi oleh berbagai bakteri yang ada di TPA [6].

Pengelolaan air lindi dapat dilakukan dengan cara mencegah air permukaan masuk kedalam lahan dan timbunan sampah yaitu dengan mengendalian air permukaan, pengisolasian timbunan sampah dengan lapisan tanah penutup, mengolah air lindi menurut kadar kandungan yang ada didalamnya sehingga air lindi dapat di salurkan ke pembuangan badan air terdekat. Tindakan pencegahan yang lainnya yaitu dengan melalui pemanfaatan sifat- sifat hidrolis dengan pengaturan air tanah sehingga aliran air lindi tidak dapat menuju ke arah air tanah [7]. Pengelolaan air lindi juga merupakan bagian dari pengelolaan lahan urug secara keseluruhan. Pada dasarnya keberhasilan penanganan lindi dimulai dari suatu lahan dipilih secara kontinyu sampai lahan tertutup penuh. Oleh sebab itu usaha penanganan air lindi ada beberapa tahap yaitu tahap pemilihan atau evaluasi lahan, tahap perancangan dan penyiapan lokasi selama proses pengoperasian, dan selama jangka waktu tertentu setelah lahan tidak digunakan lagi [8]. Beberapa jenis pengelolahan yang biasanya digunakan untuk mengelola air lindi adalah:

1. Pengelolaan kimia fisik biasanya koagulasi-flokulasi dan pengendapan.

2. Pengelolaan secara (Anaerobik), (Aerobik), dan Maturasi

3. Pemanfaatan sifat seperti kabon aktif

4. Volume kolam pengelolaan air lindi dihitung dengan satuan $\mathrm{m}^{3}$.

Dampak ialah suatu perubahan yang terjadi akibat dari aktifitas yang dapat bersifat alamiah, kimia, fisik maupun biologi. Dampak bernilai positif apabila dapat memberikan manfat bagi kehidupan manusia dan dampak bernilai negatif apabila menimbulkan resiko yang merugikan masyarakat. Berbagai macam potensi yang dapat ditimbulkan oleh dampak pencemaran akibat air lindi dan sampah meliputi: perkembangan vektor penyakit, pencemaraan udara, kemacetan lalu lintas, gangguan estetika, dan dampak sosial [9].

Permasalahan sampah yang terjadi di Kabupaten Pasuruan adalah hanya terdapat 2 (TPA). Dimana Tempat Pembuangan Akhir yang akan di bahas oleh penulis adalah TPA Kenep dimana TPA ini memiliki luas 2.9 hektar dan tempat ini hanya melayani 14 kecamatan dari 24 kecamatan di Kabupaten Pasuruan dengan luasan wilayah $1.474 .02 \mathrm{~km}^{2}$ dengan jumlah penduduk 1.605.307 jiwa. Kondisi Tempat Pembuangan Akhir (TPA) Kenep yang berada di Kabupatan Pasuruan semakin penuh dan jumlah volume sampah yang datang setiap harinya di Kabupaten Pasuruan dihasilkan dari berbagai aktivitas seperti rumah tangga, pasar, industri atau pabrik, sekolah, dan lain-lain. Berdasarkan data Dinas Lingkungan Hidup Kab. Pasuruan pada tahun 2020 jumlah timbulan sampah sekitar 7736.5 $\mathrm{m}^{3} / \mathrm{hari}$. Sampah yang dihasilkan bisa mencapai $1.934 .125 \mathrm{~kg} / \mathrm{bln}$ atau $239831.5 \mathrm{~m}^{3} / \mathrm{hari}$ dan kondisi 
TPA Kenep saat ini telah terjadi overload dapat menghasilkan dampak yang dapat meresahkan di sekitaran TPA [10].

Tempat Pembuangan Akhir Sampah Kenep di Kabupaten Pasuruan ini menggunakan metode Landfill yaitu dengan menimbun sampah di dalam tanah. Cara ini tidak dapat mengurangi volume sampah yang dibuang ke TPA. Secara tidak langsung tumpukan sampah di tempat pembuangan semakin tinggi dan lahan yaang disediakan lambat laun semakin menyempit serta kondisi alam yang kadang berubah musim dari kemaru ke musim penghujan serta air yang dapat dihasilkan dari tumpukan sampah tersebut dapat menimpulkan berbagai masalah kesehatan bagi sekitar TPA [11]. Tumpukan sampah organik yang mudah terurai mudah menghasilkan air lindi yang berbau busuk dan berpotensi dapat mencemari tanah, dan air tanah di sekitar TPA [12].

Berdasarkan permasalahan yang telah diuraikan diatas penulis melakukan analisa dampak saluran air lindi dan TPA terhadap lingkungan, sistem pengelolaan air lindi dan kebutuhan lahan di TPA Kenep Kabupaten Pasuruan. Dan tujuan dari kajian ini untuk menemukan dampak saluran air lindi dan TPA terhadap lingkungan, sistem pengelolaan air lindi dan kebutuhan lahan yang dibutuhkan sehingga memberikan manfaat serta rekomendasi secara teknis untuk mendukung sistem pengoperasian di TPA Kenep Kabupaten Pasuruan.

\section{Metode}

\subsection{Tahapan Metode Penelitian}

Jenis Metode Penelitian ini ialah penelitian deskriptif kualitatif yaitu membuat pencandraan (deskripsi) secara sistematis, akurat dan faktual [13]. Adapun ruang lingkup dan batasan penelitian dimana penelitian ini hanya membahas dampak lingkungan dari air lindi dan TPA dari segi pengelolaan kebutuhan kolam lindi dan luas lahan yang dibutuhkan.

\subsection{Pengumpulan Data}

Data primer ataupun data sekunder harus didapatkan terlebih dahulu. Data Primer diperoleh melalui survei lapangan berupa kondisi ekisting dan wawancara kepada masyarakat serta badan penanggung jawab TPA. Data Sekunder didapatkan dari instansi Dinas Lingkungan Hidup berupa hasil uji lab air lindi, perhitungan debit lindi, timbunan sampah, volume sampah dan untuk Badan Pusat Statistik (BPS) berupa jumlah penduduk.

\subsection{Perkiraan Dampak}

Dengan adanya kegiatan TPA Kenep diperkirakan akan menimbulkan dampak pada lingkungan dampak dapat bernilai positif ataupun negatif. Dampak diperkirakan akan terus berlanjut jika tidak segera diatasi dengan baik.

\subsection{Menentukan Jenis Dan Dimensi Bangunan Lindi}

Bangunan air lindi umumnya terdiri dari: Kolam Stabilisasi (Anaerobik), Kolam Fakultatif (Aerobik), dan Kolam Maturasi [14].

1. Kolam Stabilisasi (Anaerobik)

Berfungsi untuk mengurangi nilai $\mathrm{BOD}_{5}$ menggunakan proses dekomposisi secara anaerobik (tanpa udara). Waktu detensi dihitung dari beban permukaan (loading) sebesar Q air lindi x 10 gr/lt, dan volume metrik anaerobik pond $=0.193-0.240 \mathrm{~kg} / \mathrm{m}^{3}$ perhari.

2. Kolam Fakultatif (Aerobik)

Berfungsi untuk proses degradasi kontaminan organik secara aerobik dan anaerobik.

3. Kolam Maturasi

Berfungsi untuk menguraikan nutrien ( $\mathrm{N}$ dan $\mathrm{P}$ ) dan bahan organik yang masih tersisa dari proses fakultatif. Didalam kolam maturasi ini selain aktivitas mikroorganisme (bakteri) diharapkan pula aktivitas ganggang (algae). 


\section{Hasil dan PembahasanDampak Lingkungan}

\subsection{Dampak Lingkungan}

Dampak ialah suatu perubahan yang terjadi akibat dari aktifitas yang dapat bersifat alamiah, kimia, fisik maupun biologi. Berdasarkan hasil wawancara yang dilakukan kepada penduduk sekitar dan petugas penanggung jawab TPA Berbagai potensi dampak yang ditimbulkan meliputi :

\section{Perkembangan vektor penyakit}

a. Sumber dampak

Keberadaan TPA memberikan dampak untuk masyarakat sekitar TPA dimana didalamnya terdapat sampah dapur atau sampah sisa makanan adalah sumber yang sangat ideal untuk pertumbuhan pernyakit seperti tikus, lalat dan udara yang tidak sehat atau tidak sedap yang ditimbulkan oleh TPA.

b. Dampak yang terjadi

Dari dampak yang dihasilkan banyak gangguan yang dirasakan oleh warga yang berada di sekitar lokasi TPA. Kebanyakan masyarakat merasakan penyakit seperti demam, diare, penyakit kulit, dan ispa. Dan air yang digunakan oleh beberapa warga mempunyai bau dan berwana kuning kecoklatan (keruh) sehingga dapat menimbulkan penyakit gatal-gatal dan diare jika digunakan. Penyakit tersebut berhubungan dengan kualitas lingkungan (air dan udara), kondisi atau kualitas lingkungan ada keterkaitannya dengan keberadaan TPA Kenep telah mempengaruhi kesehatan masyarakat kawasan sekitar.

\section{Pencemaran udara}

a. Sumber Dampak

Sampah yang ada dan tidak tertutupi oleh urugan lapisan tanah merupakan sumber bau yang tidak sedap. Serta proses dekomposisi sampah secara berkala dapat menghasilkan gas seperti $\mathrm{CO}, \mathrm{CO} 2, \mathrm{CH}, \mathrm{H} ; \mathrm{S}$ secara tidak langsung memberikan efek emisi gas rumah kaca yang turut andil dalam pemanasan global.

b. Dampak yang terjadi

Dari dampak yang dihasilkan gangguan yang diderita oleh penduduk yang berada di dekat lokasi TPA adalah bau sampah yang sangat menyengat, jika musim penghujan tiba warga menghirup udara yang terkontaminasi dengan aroma sampah lebih pekat dari biasanya.

\section{Gangguan estetika}

a. Sumber Dampak

Tempat yang berisikan sampah akan menimbulkan pemandangan yang sangat buruk sehingga mempengaruhi keindahan lingkungan sekitarnya. Serta sarana pengangkutan dan pengumpulan yang tidak dirawat dan dibersihkan memberikan kesan yang buruk untuk sebuah layanan masyarakat.

b. Dampak yang terjadi

Dari dampak yang dihasilkan gangguan yang dirasakan oleh penduduk yang berada di dekat lokasi TPA adalah terdapat banyak karung sampah yang mengantri untuk ditimbang dan aktivitas pemilihan sampah dimana sampah di bongkar muat di jalan yang lokasinya berdekatan dengan tempat tinggal warga serta beberapa truk sampah yang selesai bongkar muatan yang tidak dibersihkan memberikan kesan yang sangat buruk.

\section{Kemacetan lalu lintas}

a. Sumber Dampak

Keberadaan TPA yang berdekatan dengan tempat yang melakukan banyak aktifitas seperti pertokoan, pasar, sekolah, kantor dan rumah penduduk berpotensi menimbulkan gangguan terhadap arus lalu lintas akibat kegiatan bongkar muat sampah yang đilakukan dan antrian giliran untuk ditimbang.

b. Dampak yang terjadi

Dari dampak yang dihasilkan gangguan yang diderita penduduk yang berada di dekat lokasi TPA adalah ketika truk sampah datang secara bersamaan dan mengantri untuk 
ditimbang dan adanya tumpukan sak sampah di pinggiran jalan yang menunggu untuk di timbang juga membuat menyempitnya jalan hingga akses keluar masuk warga sedikit terganggu, meskipun proses antri dan bongkar muatan dilakukan di siang hari dimana minimnya aktifitas yang dilakukan oleh penduduk sekitar lokasi TPA.

\section{Dampak sosial}

a. Sumber Dampak

Keberadaan Tempat Pembuangan Akhir (TPA) Kenep di Kabupaten Pasuruan dengan segala aktifitasnya memberikan dampak sosial terhadap masyarakat setempat seperti penurunan kualitas kesehatan, lingkungan dan kenyamanan.

b. Dampak Yang Terjadi

Dampak sosial yang dihasilkan dari keberadaan TPA Kenep ini adalah penurunan kualitas kesehatan, lingkungan dan kenyamanan. Ditinjau dari penurunan kualitas kesehatan banyaknya jenis penyakit yang diderita oleh warga sekitar seperti demam, diare, penyakit kulit, dan ispa. Untuk lingkungan secara keseluruhan tidak menyebabkan kerusakan lingkungan yang berarti. Namun terjadi polusi udara yaitu berupa bau yang ditimbulkan dari keberadaan TPA Kenep. Sedangkan dari segi kenyamanan secara keseluruhan sebagian besar masyarakat beranggapan terganggu dengan keberadaan TPA Kenep.

Berdasarkan hasil pembahasan yang dilakukan bahwasannya keberadaan TPA Kenep dengan segala aktifitasnya memberikan dampak negatif terhadap masyarakat yang ada disekitar TPA. Hal ini senada dengan penelitian lainnya dengan adanya TPA dilokasi yang berdekatan dengan pemukiman memberikan dampak negatif bagi kesehatan dan sosial masyarakat [15].

\subsection{Menghitung Dimensi Instalasi Pengelolahan Air Lindi}

Luas area lahan TPA Kenep tahun 2020 sekitar 2.9 Ha. Digunakan sebagai sarana prasarana penunjang sekitar $20 \%$ yaitu sebesar $0.58 \mathrm{Ha}$.

\section{Perhitungan Kolam Stabilisasi (Anaerobik)}

Menghitung nilai Q dengan menggunakan Metode Rasional hasil perhitungan Q diperoleh dari instansi terkait yaitu Dinas Lingkungan Hidup Kab. Pasuruan sebagai berikut:

$Q=\frac{\frac{C \times I \times A}{360} m^{3}}{d t}$

$\mathrm{C}=$ Koefisien aliran permukaan (Mc Guen, 1989) digunakan 0.50 (Hutan bergelombang 5\% $10 \%$ ) (untuk asumsi bukit sampah)

$\mathrm{I}=$ Intesitas Hujan $\quad=1500 \mathrm{~mm} / \mathrm{th}=0,1712 \mathrm{~mm} / \mathrm{jam}$

$\mathrm{A}=2,9 \mathrm{Ha}$

$Q=\frac{0,50 \times 0,1712 \times 2,9}{360}=0,000689 \mathrm{~m}^{3} / \mathrm{dt}=0,000689 \times 1000=0,689 \mathrm{lt} / \mathrm{dt}$

Sumber: Perhitungan Dinas Lingkungan Hidup Kab. Pasuruan.

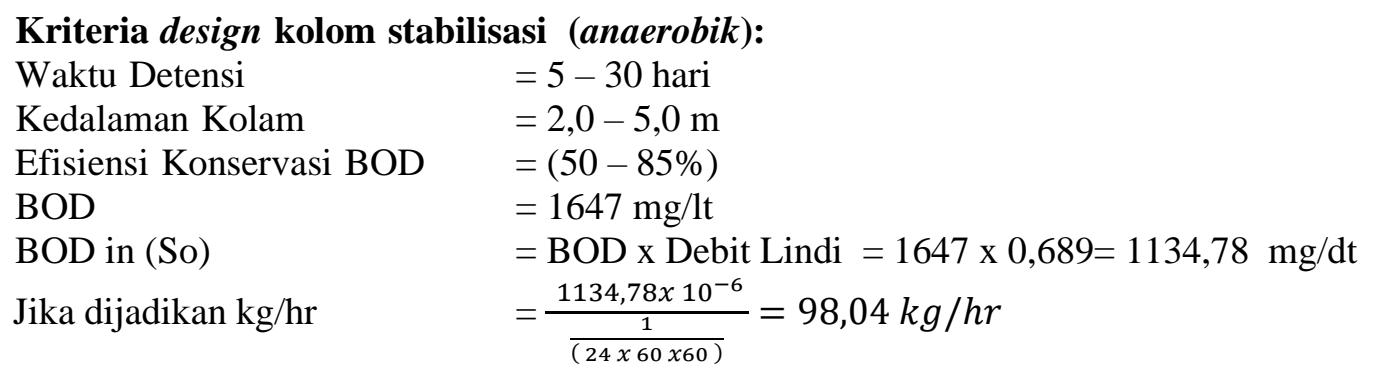

Menghitung rencana instalasi pengelolaan lindi yang dilaksanakan:

Waktu Detensi (td) $=5 \mathrm{hr}$

Konstanta laju penyisihan K' diambil $=0,1 \mathrm{hr}$ 


\section{Menghitung Debit Air Lindi:}

$\mathrm{Q}=0,689 \mathrm{lt} / \mathrm{dt}$

Jadi vol. kolam

$=$ Debit lindi $\times 10^{-3}=\frac{0,689 \times 10^{-3}}{\frac{1}{(24 \times 60 \times 60)}}=59,53 \mathrm{~m}^{3} / \mathrm{hr}$

Jika kedalaman kolam 3,5 m

$=\mathrm{V}=\mathrm{Q} \times \mathrm{t}=59,53 \times 5=297,65 \mathrm{~m}^{3}$

Maka luas kolam anaerobik

$=\frac{297,65}{3,5}=85,04 \mathrm{~m}^{2}$

Jadi luas total untuk kolam Stabilisasi (Anaerobik) sebesar 85,04 $\mathrm{m}^{2}$

Menghitung BOD yang dikeluarkan di kolam stabilisasi (anaerobik):

S

$$
\begin{aligned}
& =\frac{S o}{\left(1+K^{\prime} \times t\right)}=\frac{1647}{1+0,1 \times 5}=1098 \frac{\mathrm{mg}}{\mathrm{lt}} \\
& \left.=\frac{1098}{1647} \times 100=67 \% \text { (biasanya diantara } 50-80 \%\right)
\end{aligned}
$$

Mempunyai Efisiensi

Konstruksi kolam dibuat dari konstruksi beton bertulang.

2. Perhitungan Kolam Fakultatif (Aerobik)

Kriteria design kolam fakultatif (aerobik):

Kedalaman

$$
=2-3 \mathrm{~m}
$$

Waktu Detensi (td)

$=5-15$ hari

Efesiensi Konservasi BOD

Menghitung hasil kolam stabilisasi anaerobik yang dikeluarkan:

BOD in (So) = BOD anaerobik $\mathrm{x}$ Debit lindi

$\begin{aligned} & =1098 \times 0,689=756,52 \mathrm{mg} / \mathrm{lt} \\ \text { Jika di jadikan } \mathrm{kg} / \mathrm{hr} & =\frac{756,52 \times 10^{-6}}{\frac{1}{(24 \times 60 \times 60)}}=65,36 \mathrm{~kg} / \mathrm{hr}\end{aligned}$

Menghitung rencana instalasi pengelolaan lindi yang akan dilaksanakan dihitung seperti:

Debit Lindi

Waktu detensi (td)

Konstanta laju penyisihan K' diambil

Menentukan Debit Air Lindi Q

$$
\begin{aligned}
& =0,689 \mathrm{lt} / \mathrm{det} \\
& =10 \mathrm{hr} \\
& =0,15 \mathrm{hr} \\
& =0,689 \mathrm{lt} / \text { detik }=\text { Debit lindi } \times 10^{-3} \\
& =\frac{0,689 \times 10^{-3}}{\frac{1}{(24 \times 60 \times 60)}}=59,53 \mathrm{~m}^{3} / \mathrm{hr}
\end{aligned}
$$

\section{Menghitung vol kolam fakulatif (aerobik)}

$$
\begin{array}{ll}
\mathrm{V}=\mathrm{Q} \times \mathrm{t} & =59,53 \times 10=595,3 \mathrm{~m}^{3} \\
\text { Jika kedalaman kolam } & =3 \mathrm{~m} \\
\text { Maka total luasan kolam A } & =\frac{595,3}{3}=198,43 \mathrm{~m}^{2}
\end{array}
$$

Jadi luas total untuk kolam Fakultatif (Aerobik) sebesar 198,43 m²

Menghitung BOD yang dikeluarkan di kolam fakulatif (Aerobik):

$$
\begin{array}{ll}
\mathrm{S}=\frac{\text { So }}{\left(1+K^{\prime} \times t\right)} & =\frac{1098}{1+0,1 \times 10}=549 \mathrm{mg} / \mathrm{lt} \\
\text { Mempunyai Efisiensi } & =\frac{549}{1098} \times 100=50 \% \text { (biasanya diantara } 50-80 \% \text { ) }
\end{array}
$$

3. Perhitungan Kolam Maturasi

Kriteria design kolam maturasi:
Kedalaman
$=2-3 \mathrm{~m}$
Waktu Detensi (td)
$=5-15 \mathrm{hr}$
Efesiensi Konservasi BOD

$$
=50-80 \%
$$


Untuk mencapai penurunan BOD yang diharapkan paling tidak dapat mencapai 50\%: $\mathrm{BOD}$ in $(\mathrm{So}) \quad=549 \mathrm{mg} / \mathrm{lt}$ $=$ BOD aerobic $\times$ Debit Lindi $=549 \times 0,689=378,26 \mathrm{mg} / \mathrm{lt}$

Jika dijadikan $\mathrm{kg} / \mathrm{hr} \quad=\frac{378,26 \times 10^{-6}}{\frac{1}{(24 \times 60 \times 60)}}=32,68 \mathrm{~kg} / \mathrm{hr}$

Menghitung rencana instalasi pengelolaan lindi yang akan dilaksanakan dihitung seperti:

Konstanta laju penyisihan K' diambil $\quad=0,15 \mathrm{hr}$

Debit air lindi Q

$=0,689 \mathrm{lt} / \mathrm{det}$

Waktu detensi diambil

$=10 \mathrm{hr} .$.

Maka vol. kolam maturasi

$\mathrm{V}=\frac{Q \times t \times 24 \times 60 \times 60}{1000}$

$=\frac{0,689 \times 10 \times 24 \times 60 \times 60}{1000}=595,3 \mathrm{~m}^{3}$

Jadi total volume kolam maturasi sebesar $\mathrm{V}=595,3 \mathrm{~m}^{3}$

Jika kedalaman kolam maturasi $3 \mathrm{~m}$

Maka luas kolam maturasi A

$=\frac{595,3}{3}=196,43 \mathrm{~m}^{2}$

Jadi luas total untuk kolam Maturasi sebesar 198,43 $\mathrm{m}^{2}$

Menghitung BOD yang dikeluarkan di kolam maturasi:

$\mathrm{S}=\frac{S o}{\left(1+K^{\prime} x t\right)} \quad=\frac{549}{1+0,1 \times 10}=275 \mathrm{mg} / \mathrm{lt}$

Mempunyai Efisiensi $\quad=\frac{275}{549} \times 100=50 \%$ (biasanya diantara $50-80 \%$ )

Maka hasil kebutuhan luas lahan minimum untuk instalasi pengelolaan air lindi (IPAL) direncanakan untuk mengelola air lindi yang dihasilkan dari pengurungan sampah (Landfill) di TPA Kenep seluas 2,9 ha dapat di lihat di Tabel 1 di bawah ini:

Tabel 1. Kebutuhan luas lahan minimum untuk IPAL TPA Kenep

\begin{tabular}{|c|c|c|c|c|c|c|c|}
\hline $\begin{array}{c}\text { Unit } \\
\text { Pengolah }\end{array}$ & $\begin{array}{c}\text { Volum } \\
\text { e } \\
\left(\mathbf{m}^{3}\right) \\
\end{array}$ & $\begin{array}{c}\text { Tingg } \\
\text { i } \\
(\mathbf{m}) \\
\end{array}$ & $\begin{array}{c}\text { Luas } \\
\left(\mathbf{m}^{2}\right)\end{array}$ & $\begin{array}{c}\text { Panjan } \\
\text { g } \\
(\mathrm{m})\end{array}$ & $\begin{array}{c}\text { Lebar } \\
(\mathrm{m})\end{array}$ & $\begin{array}{c}\text { Waktu } \\
\text { Detens } \\
\text { i } \\
(\text { hr }) \\
\end{array}$ & $\begin{array}{c}\text { Effetivita } \\
\text { s } \\
(\%) \\
\end{array}$ \\
\hline Stabilisasi & 297.5 & 3.5 & $\begin{array}{l}85.04 \\
198.4\end{array}$ & 10 & 8.5 & 5 & $67 \%$ \\
\hline Fakulatif & 595.3 & 3 & $\begin{array}{c}3 \\
198.4\end{array}$ & 15 & 13.23 & 10 & $50 \%$ \\
\hline Maturasi & 595.3 & 3 & 3 & 15 & 13.23 & 10 & $50 \%$ \\
\hline Total & 1488.1 & & 481.9 & & & 25 & \\
\hline
\end{tabular}

\subsection{Perhitungan Menentukan Lahan Untuk TPA Kenep}

a. Menghitung sampah dalam $\mathrm{m}^{3} / \mathrm{hari}$. Diambil bulan terakhir pada tahun 2020 yaitu Desember 2020 dimana masih dalam satuan $\mathrm{kg} / \mathrm{bln}$ dirubah menjadi $\mathrm{m}^{3} / \mathrm{bln}$ $\left(1 \mathrm{~m}^{3}=250 \mathrm{~kg}\right) \quad=1.934 .125 \mathrm{~kg} / \mathrm{bln}: 250 \mathrm{~kg} / \mathrm{bln}=7736,5 \mathrm{~m}^{3} / \mathrm{bln}$

Kemudian dari $\mathrm{m}^{3} / \mathrm{bln}$ dijadikan $\mathrm{ke} \mathrm{m}^{3} / \mathrm{hr}=\frac{7736,5}{30}=258 \mathrm{~m}^{3} / \mathrm{hr}$

b. Menghitung luas yang dibutuhkan untuk TPA Kenep dengan kedalam sampah $15 \mathrm{~m}$ $\mathrm{A}=\frac{258 \times 365}{15}=6278 \mathrm{~m}^{2}=\frac{6278}{10000}=0,6$ hektar

Berdasarkan hasil perhitungan diatas diketahui kebutuhan kapasitas luas area untuk TPA Kenep adalah 0.6 hektar. Luas area total lahan TPA Kenep tahun 2020 sekitar 2.9 Ha dan digunakan sebagai sarana prasarana penunjang sekitar $20 \%$ yaitu sebesar $0.58 \mathrm{Ha}$. 
Kondisi TPA Kenep saat ini telah terjadi overload maka diperlukan perluasan lahan sebesar 0.6 Ha untuk TPA dan digunakan sebagai sarana prasarana penunjang sekitar $20 \%$ yaitu sebesar $0.1 \mathrm{Ha}$. Untuk dapat mengatasi masalah overload yang sedang terjadi bisa dilakukan tindakan pemilahan sampah/pengurangan sampah sejak dari sumbernya oleh masyarakat agar dapat membantu mengatasi overload yang terjadi TPA [16]. Hal ini dapat dilakukan oleh masyarakat dengan melalui sistem R3 yaitu sistem pengurangan (Reduce), penggunaan kembali (Reuse), dan didaur ulang kembali (Recycle). Oleh sebab itu perlunya kontribusi masyarakat dalam pemberdayaan terhadap pengelolaan sampah sebelum diangkut ke tempat pembuangan akhir [17].

\section{Kesimpulan}

Dari hasil uraian diatas analisa dampak saluran air lindi terhadap lingkungan di TPA Kenep, Kecamatan Beji, Kabupaten Pasuruan didapatkan kesimpulan yaitu:

1. Dampak yang dihasilkan dari beroperasinya TPA Kenep dan saluran air lindi ini memberikan dampak negatif bagi masyarakat yang tinggal di sekitar TPA seperti Masalah kesehatan, Pencemaran udara, Gangguan estetika, Kemacetan lalu lintas, dan Dampak sosial.

2. Tempat Pembuangan Akhir ini juga sudah di nilai berada di kondisi tidak higienis dan mudah sekali dalam masalah terutama masalah lingkungan dimana metode Landfill pun bisa mengakibatkan dampak di TPA itu sendiri karena jumlah sampah $258 \mathrm{~m} 3 / \mathrm{hr}$, maka diperlukan perluasan lahan sebesar 0.6 Ha untuk TPA dan digunakan sebagai sarana prasarana penunjang sekitar $20 \%$ yaitu sebesar $0.1 \mathrm{Ha}$.

3. Dengan debit air lindi yang didapat sebesar $0.689 \mathrm{lt} / \mathrm{dt}$ maka didapatkan Kebutuhan luas lahan minimum untuk IPAL :

- Kolam Stabilisasi (Anaerobic) yaitu luas sebesar $85.04 \mathrm{~m}^{2}$, kedalaman sebesar $3.5 \mathrm{~m}$, panjang 10 $\mathrm{m}$, lebar $8.5 \mathrm{~m}$, dan hasil efisiensi sebesar $67 \%$.

- Kolam Fakultatif (Aerobic) yaitu luas sebesar 198.43 m², kedalaman sebesar 3 m, panjang 15 m, lebar $13.23 \mathrm{~m}$ dan hasil efisiensi sebesar $50 \%$.

- Kolam Maturasi yaitu luas sebesar $198.43 \mathrm{~m}^{2}$, kedalaman sebesar $3 \mathrm{~m}$, panjang $15 \mathrm{~m}$, lebar 13.23 $\mathrm{m}$ dan hasil efisiensi sebesar $50 \%$.

\section{Referensi}

[1] Saleh, C. (2012). Studi Perencanaan Instalasi Pengelolaan Limbah Lindi Sebagai Kontrol Pemenuhan Baku Mutu Sesuai KEPMEN 03/91 (Studi Kasus Pada TPA Supit Urang Malang). Media Teknik Sipil, 10(2), 87-94, 2012.

[2] Suprihatin, H. (2014). Penurunan Konsentrasi BOD Limbah Domestik menggunakan Sistem Wetland dengan Tanaman Hias Bintang Air (Cyperus alternifolius), Dinas Lingkung. Indonesia., 1(2), 80-87, 2014.

[3] Raharjo, I., Suprapto., \& Zulkarnain, I. (2013). Perencanaan Kolam Stabilisasi Untuk Penanganan Air Lindi (Leachate) Pada Calon Tempat Pembuangan Akhir (TPA) Kabupaten Mesuji., 5(1), 2013.

[4] Widiarti, I., W., \& Muryani, E. (2018). Kajian Kualitas Air Lindi Terhadap Kualitas Air Tanah Di Sekitar TPA Jetis, Desa Pakem, Kecamatan Gebang, Purworejo, Jawa Tengah. J.Tanah dan Air., 15(1), 2018.

[5] Hartini, E., \& Yulianto, Y. (2018). Kajian Dampak Pencemaran Lindi Tempat Pemrosesan Akhir (TPA) Ciangir Terhadap Kualitas Air dan Udara. Jurnal Siliwaangi., 4(1), 2018.

[6] Sukorini, T., Budiastuti, S., Handono, A. R. \& Kafir, F. P. (2014). Kajian Dampak Timbunan Sampah Terhadap Lingkungan Di Tempat Pembuangan Akhir (TPA) Putri Cempo Surakarta. Jurnal EKOSAINS, 6(3), 2014. 
[7] Pajooh, E. M., Weichgrebe, D., \& Cuff, G. (2017). Municipal Landfill Leachate Characteristics and Feasibility of Retrofitting ExistingTreatment Systems with Deammonification-A Full Scale Survey, J. Environ. Manage., 187(2), 354-364, 2017.

[8] Usman, S., \& Santosa, I. (2014). Pengolahan Air Limbah Sampah (Lindi)dari Tempat Pembuangan Akhir Sampah (TPA) menggunakan Metoda Constructed Wetland, J. Kesehatan., 5(2), 98-108, 2014.

[9] Sulistyowati. (2011). Analisis Mengenai Dampak Lingkungan (AMDAL) Dalam Pengelolaan Sampah Kota (Studi Akses Masyarakat dalam AMDAL di Lokasi Ngronggo Salatiga). Journal of Environmental Management, 38(5), 14-44.

[10] Dinas Lingkungan Hidup Kabupaten Pasuruan 2020

[11] Yao, P. (2013). Perspectives on Technology for Landfill Leachate Treatment,Arab. J. Chem., 10(2), 1-8, 2017.

[12] Husna, L. F., \& Emenda S. (2017). Assesment Of Groundwater Countamination By Leacheate Around Supit Urang Landfill, Malang. Jurnal Teknik Lingkungan., 23(1), 2017.

[13] Sidik, M., A. (2011). Peran adipura pada pelaksanaan sistem pengelolaan sampah di indonesia. Teknologi Lingkungan, 12(3), 319-33, Retrieved from, 2011.

[14] Suprihatin, H. (2014). Penurunan Konsentrasi BOD Limbah Domestik menggunakan Sistem Wetland dengan Tanaman Hias Bintang Air (Cyperus alternifolius), Din. Lingkung. Indones., 1(2), 80-87, 2014.

[15] Yusmiati. (2017). Dampak Keberadaan Tempat Pembuangan Akhir (TPA) Muara Fajar Terhadap Sosial Ekonomi Masyarakat Di Kelurahan Muara Fajar Kecamatan Rumbai Kota Pekanbaru. JOM Fekon., 4(1) 2017.

[16] Mulasari, A., Husodo, A. heru, \& Muhadjir, N. (2016). Analisis Situasi Permasalahan Sampah Kota Yogyakarta Dan Kebijakan Penanggulangannya. Jurnal Kesehatan Masyarakat, 11(2), 96-106, 2016

[17] Sukorini, T., Budiastuti, S., Handono, A. R. \& Kafir, F. P. (2014). Kajian Dampak Timbunan Sampah Terhadap Lingkungan Di Tempat Pembuangan Akhir (TPA) Putri Cempo Surakarta. Jurnal EKOSAINS, 6(3), 2014. 